\title{
Muerte y política: los funerales de Rufino Ortega y José Néstor Lencinas (Mendoza, principios del siglo XX)
}

\author{
[Death and politics: the Funerals of Rufino Ortega and José Néstor Lencinas \\ (Mendoza, early 20 ${ }^{\text {th }}$ Century)]
}

\author{
Rosana Aguerregaray Castiglione \\ INCIHUSA, CCT- Mendoza, CONICET \\ raguerregaray@mendoza-conicet.gob.ar
}

\begin{abstract}
Resumen
El presente trabajo analiza los funerales de los exgobernadores de la provincia de Mendoza, Rufino Ortega y José Néstor Lencinas, quienes fallecieron en las primeras décadas del siglo XX en una coyuntura política y social inestable. Si bien estas ceremonias organizadas por el Estado presentaron ciertas características similares, también manifestaron particularidades que apuntaron a subrayar los valores identitarios del partido en el cual estos hombres habían militado y así legitimar su propio gobierno.
\end{abstract}

Palabras clave: Funerales - Gobernadores Estado - Fines Pedagógicos - Siglo XX

\begin{abstract}
The present work investigates the funerals of former governors of the province of Mendoza Rufino Ortega and Jose Néstor Lencinas, who died in the first decades of the twentieth century in an unstable political and social conjuncture. Although these ceremonies, organized by the State, presented certain similar characteristics, they also manifested certain particularities that were aimed at underlining the identity values of the party in which these individuals had militated and thus legitimize their own government.

Keywords: Funeral - Governors - State Pedagogical Purposes - Twentieth Century
\end{abstract}

Recibido: $12 / 05 / 2017$

Evaluación: 21/09/2017

Aceptado: 06/02/2018

Anuario de la Escuela de Historia Virtual - Año 9 - No 13 - 2018: pp. 42-66.

ISSN: 1853-7049

http://revistas.unc.edu.ar/index.php/anuariohistoria 


\section{Muerte y política: los funerales de Rufino Ortega y José Néstor Lencinas (Mendoza, principios del siglo XX)}

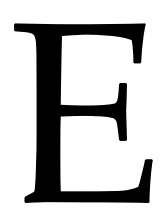

1 presente artículo tiene como objetivo analizar las diferentes instancias de los funerales de los exgobernadores mendocinos, Rufino Ortega y José Néstor Lencinas, organizados por el Estado Provincial. Se apunta a detectar los rasgos compartidos de estas ceremonias, pero también a subrayar las particularidades, relacionando estas prácticas fúnebres con la coyuntura política y sociocultural en la cual se desarrollaron. Si bien ambos fueron gestionados por esta institución, se hizo hincapié en diferentes aspectos del trayecto profesional y de la gestión de estos actores políticos -a pesar de desarrollarse en la misma coyuntura- ya que representaban a fracciones opuestas.

Rufino Ortega, integrante de los denominados gobiernos "oligárquicos", ${ }^{1}$ falleció en noviembre de 1917, en un momento político singular, ya que, a los pocos días, Mendoza fue intervenida bajo la orden del entonces presidente de la nación Hipólito Yrigoyen. Al año siguiente, llegó al poder la Unión Cívica Radical (UCR) por vía constitucional y fue proclamado gobernador de la provincia José Néstor Lencinas quien falleció dos años después en pleno ejercicio de su mandato.

De este modo, se parte del supuesto de que ambos funerales ${ }^{2}$ fueron empleados por el Estado provincial como una herramienta pedagógica ya que presentaron ciertos aspectos similares; pero también ciertas peculiaridades manifestadas en la estética, la intención y el mensaje que se quería transmitir, concordantes con los aspectos o valores que el gobierno de turno buscaba resaltar para reforzar y legitimar su propia gestión e identidad partidaria.

\footnotetext{
${ }^{1}$ Según Richard Jorba y Bragoni, la oligarquía consistió en un grupo reducido ubicado en la cúspide de la sociedad que controlaba el poder. Sus miembros garantizaban la sucesión en los puestos políticos, asegurando su perdurabilidad en el poder y, así, evitaban todo posible triunfo de la oposición. Sostienen que para el caso de Mendoza con posterioridad a la batalla de Pavón, se evidenció en el seno de la elite, una conformación oligárquica, al modo planteado por Botana para la dirigencia nacional (Richard Jorba y Bragoni, 1998). Además, Richard Jorba (2009, p. 4) menciona que este subgrupo denominado oligarquía habría estado integrado por "familias ricas y notables" que establecieron "una verdadera simbiosis entre lo público y lo privado, entre el poder económico y el político". Progresivamente, los miembros de oligarquía, que provenían de la actividad comercial, fueron controlando la económica y los cargos políticos, logrando comandar a la elite, y de este modo, excluyeron a la oposición que también provenía del seno mismo de este grupo (Richard Jorba, 2009).

2 Según Ben-Amos, estos funerales, más allá de su condición de ritos de pasaje, constituyen ceremonias de poder que forman parte de todo régimen político, siendo un componente fundamental para la construcción de la versión del pasado que se quiere instaurar como parte de la memoria oficial (Ben-Amos, 2000).
} 
44 I Muerte y política: los funerales de Rufino Ortega...

Para llevar a cabo este trabajo se analizan los decretos y las disposiciones oficiales, las notas y fotografías de la prensa y las revistas locales, publicadas en Los Andes, ${ }^{3}$ La Palabra $^{4}$ y La Quincena Social ${ }^{5}$. Los documentos permiten indagar en el protocolo establecido por el Estado provincial en este tipo de ceremonias y en cuestiones relacionadas con las prácticas fúnebres en el ámbito privado y público.

\section{Rufino Ortega: la muerte de un político "progresista"}

En noviembre de 1917, falleció el teniente general Ortega ${ }^{6}$ quien fue gobernador de la provincia durante el período comprendido entre 1884 y 1887. Formó parte de los llamados "gobiernos liberales" que mantuvieron el poder prácticamente hasta 1918, aunque no sin tensiones ni conflictos. Estos gobiernos de familia, de carácter liberal en lo económico y conservador en lo político, contribuyeron a la conformación de la Mendoza moderna, vitícola y agroindustrial (Jorba, 2010). Este nuevo perfil, asociado a la inmigración europea, produjo profundos cambios sociales que llevaron a un acelerado proceso de concentración poblacional. No obstante, trajo aparejado los primeros desajustes del ambiente urbano; un ejemplo de ello fue el desarrollo de la epidemia de cólera en el verano de 1886 y 1887.

El gobernador Ortega fue un destacado militar. Su rol en el ejército le posibilitó el acceso a determinados recursos, como la movilización de hombres, ganado y armas en tiempos de elecciones y conflictos. Estos le sirvieron de capital político que fue puesto al servicio del "partido liberal". A partir de 1873, los "liberales" se fracturaron en "civitistas" y "gonzalistas" y Ortega adhirió a los primeros, que conformaron el oficialismo junto con los Villanueva, los Civit y los Benegas. En ese mismo año, además, intervino activamente en las elecciones como comandante de guardias nacionales de Maipú, donde amedrentó a los opositores mediante la violencia.

\footnotetext{
${ }^{3}$ Los Andes fue creado en 1883 por Adolfo Calle, durante la gobernación de José Miguel Segura, y continúa hasta la actualidad. En sus inicios, tenía tirada los días martes, jueves y sábados, hasta 1903 que comenzó a publicarse todos los días. Fue un periódico independiente con su propia editorial desde 1887. Fue opositor del gobierno de Rufino Ortega, mientras que La Palabra era el diario oficialista. Por otra parte, en 1888, las autoridades eclesiásticas prohibieron su lectura por la publicación de algunos artículos que se decían atentar contra la religión católica, no obstante, se declaró de libre pensamiento, simpatizando con los preceptos de la masonería y criticando a dicho culto. Posteriormente, durante los gobiernos lencinista fue el diario opositor, mientras que La Palabra era el oficialista (Oviedo, 2010).

${ }^{4}$ La Palabra surgió en 1885 -tras la desaparición de El Constitucional- durante la gobernación de Ortega y constituyó el diario oficialista. Tuvo tirada hasta 1889 y volvió a resurgir durante el periodo comprendido entre 1913 y 1935, siendo simpatizante del gobierno radical lencinista.

${ }^{5}$ La Quincena Social tuvo tirada desde 1920 hasta 1935, siendo su fundador Leonardo Napolitano. Trató diversas temáticas culturales: literatura, arte y crítica (Oviedo, 2010).

${ }^{6}$ Ortega nació en 1847 en Mendoza, era hijo del militar José Rufino Ortega y Teresa Molina (hija del gobernador Pedro Molina). En 1871, se casó con Elvira Ozamis y en 1904 con Leonor Solanilla. Estuvo emparentado, a través de sus hijos, con los Quiroga, los Civit y los Benegas. Fue un importante propietario y comerciante. Además, fue diputado provincial (1873-1874), jefe de policía (1876-1878) y senador nacional (1887) (García Garino, 2017).
}

Anuario de la Escuela de Historia Virtual - Año 9 - N 13 - 2018: pp. 42-66. ISSN 1853-7049 
Sin embargo, en la década de 1880, en el marco de los enfrentamientos internos del Partido Autonomista Nacional (PAN), fue partidario del presidente Juárez Celman en sus disputas con el expresidente Julio A. Roca. De este modo, siendo jefe de policía hizo una revolución contra el entonces gobernador Tiburcio Benegas, quien respondía a Roca. A esta tensión en el ámbito político local se sumó el estallido de la revolución cívica en Buenos Aires de 1890 (García Garino, 2017).

Este partido - del cual formaba parte Ortega- estaba integrado por un grupo de familias tradicionales con cierta posición económica y prestigio social surgidas de una red de alianzas que no respondían a normativas para ocupar cargos en el poder. Así, “la recurrencia al fraude les evitaba el reclutamiento de adherentes y la ampliación de sus bases o la constitución de un aparato centralizado" (Persello, 2010, p. 65).

Esta estructura institucional establecida a fines del siglo XIX continuó en las primeras décadas del siglo XX, más allá de las modificaciones que implicó en la cultura política el ascenso del radicalismo, basado en un liderazgo de tipo popular. A fines de noviembre de 1917, Hipólito Yrigoyen -representante de la UCR- ordenó intervenir la provincia que se encontraba al mando de los conservadores. Desde la perspectiva radical, las intervenciones permitirían restituir las autonomías provinciales otorgándole al pueblo la posibilidad de elegir a sus propios gobernantes que hasta ese momento eran designados por agentes del poder central; así como también "establecer el pleno ejercicio de la vida institucional, a restaurar su soberanía mutilada, a superar el vicio, el desorden y la corrupción de las costumbres públicas y privadas y a establecer la justicia" (Persello, 2010, p. 82).

En ese contexto turbulento murió Ortega y frente a ello, el diario Los Andes manifestaba que su desaparición privaba a la provincia y a la nación del militar de graduación más alto que "encarnaba la vieja tradición del militarismo argentino". Por ello, se enaltecía la imagen del difunto: "[...] su actuación militar llena de episodios de valor y de lealtad, ejercida desde la modesta esfera de soldado raso, el extinto desarrolló actividades políticas en Mendoza [...]. Vinculó su nombre a diversos progresos y acontecimientos"7. La prensa destacaba su carrera militar cuyo desempeño "fue brillante" y con la cual consiguió uno de sus mayores logros: la ocupación del fuerte General San Martín, punto más avanzado de la línea de fronteras al sur de Mendoza, en donde con un "atrevido avance [de] 6 oficiales y 80 hombres de tropa [llegó] hasta las cercanías del Neuquén con el mayor éxito (sic)" ${ }^{8}$

De este modo, el gobierno manifestó que debido al fallecimiento del exgobernador que había "coadyuvado al progreso" de la provincia y del país "con todo patriotismo" y por su destacada "actuación en las campañas del Paraguay y del desierto", era pertinente rendir los siguientes honores:

\footnotetext{
7 Diario Los Andes, 21 de noviembre de 1917, “Teniente general Rufino Ortega”, p 6.
}

8 Diario Los Andes, 21 de noviembre de 1917, “Teniente general Rufino Ortega”, p. 6. 
Art. $1^{\circ}$ Durante tres días, la bandera nacional permanecerá izada a media asta en todos los edificios públicos de la provincia.

Art. $2^{\circ}$ Por el ministro de gobierno se dispondrá lo conducente para que los restos [...] sean trasladados á la casa de gobierno donde serán velados y conducidos desde allí el día de mañana á las 5 p.m. al cementerio municipal, debiendo concurrir el poder [...].

Art. $3^{\circ}$ [Se designará una comisión para que acompañe los restos].

Art. $4^{\circ}$ La jefatura de policía impartirá las órdenes necesarias á fin de que fuerzas de su dependencia rindan los honores correspondientes á gobernador de la provincia, en la traslación de los restos y en el acto de su inhumación en el cementerio.

Art. $5^{\circ}$ Remítase á la familia del extinto la nota de pésame acordada... ${ }^{9}$

Los restos fueron conducidos a la Casa de Gobierno - “altar mayor del poder político" (Gayol, 2012, p. 8) - y allí se levantó la capilla ardiente, sencilla e imponente, completamente tapizada de negro y con altos candelabros de estilo Luis XV. Hicieron guardia de honor una sección del cuerpo de agentes de policía y de bomberos, de los Regimientos $16^{\circ}$ de Infantería y $1^{\circ}$ de Artillería; este último formó parte de los honores militares. ${ }^{10}$ En el centro de la escena, fue colocado el ataúd de roble cubierto con la bandera nacional otorgada por el gobierno provincial-y las banderas de los regimientos mendocinos, la espada, el keps y las medallas; símbolos que aludían a su carrera militar. ${ }^{11}$ Su cuerpo fue amortajado con el uniforme del ejército e insignias, tal como lo muestra la fotografía de su velorio (imagen 1 ).

\section{Imagen 1. Velorio de Rufino Ortega ${ }^{12}$}

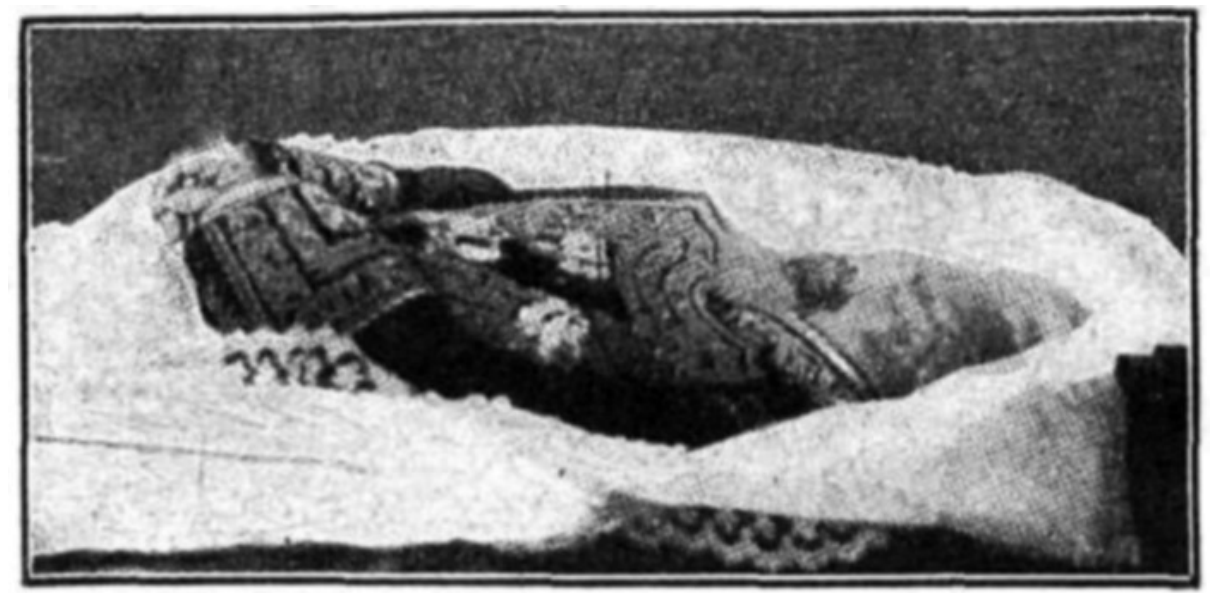

\footnotetext{
9 Diario Los Andes, 21 de noviembre de 1917, “Teniente general Rufino Ortega", p. 6.

${ }^{10}$ Diario Los Andes, 21 de noviembre de 1917, “Teniente general Rufino Ortega", p. 6.

${ }^{11}$ Diario La Tarde, 21 de noviembre de 1917, “Fallecimiento del Teniente General D. Rufino Ortega”, p. 4.

${ }^{12}$ Este tipo fotografías es probable que fuera una de las primeras en publicarse en la prensa local, ya que anteriormente, en los diarios consultados no se han encontrado. Estas fueron difundidas en el diario local Los Andes y en la revista Caras y Caretas de Buenos Aires (Revista Caras y Caretas, 1 de diciembre de 1917, “El fallecimiento del teniente general Ortega", p. 67).
} 
Frente al féretro desfiló un conjunto de actores vinculados al Poder Ejecutivo, Legislativo y Judicial, además de los deudos y de una multitud de diferente rango etario, grupo social y género. Según la prensa, la población transitó durante toda la noche y la mañana; llegaron a registrarse cinco mil personas hasta ese momento. ${ }^{13}$ El periódico expresaba que el pueblo nunca había manifestado tan "espontáneo y [...] sincero duelo como el de ayer en homenaje á la figura más alta del ejército, el teniente general D. Rufino Ortega". ${ }^{14}$ De tal forma, a medida "que se aproximaba la hora de la partida del cortejo, frente á la casa de gobierno se formaban aglomeraciones populares" y "cuando se aproximaba la hora anunciada, seguía más intenso el desfile de pueblo ante el catafalco (sic)" ${ }^{15}$ El cadáver, en el centro de la escena, era "el articulador de la ceremonia y el principal portador de significados" (García Ferrari y Gayol, 2015, p. 64).

En horas de la mañana se ofició la misa de cuerpo presente en sufragio del alma del extinto; asistieron los familiares, damas de la sociedad, autoridades civiles y militares. ${ }^{16}$ Este tipo de exequias mostró ciertas particularidades, ya que no se realizó en las iglesias, tal como lo prohibió la normativa de $1896,{ }^{17}$ ni tampoco en la vivienda familiar como era costumbre; sino que, por el contrario, se celebró en el edificio público más representativo del Poder Ejecutivo. A ello se sumó que los deudos manifestaban en el aviso fúnebre que el general había fallecido confortado con los auxilios de la santa religión, de acuerdo con los principios del "buen morir" establecidos por la Iglesia Católica. ${ }^{18}$

Luego, una vez concluido el velorio, el cajón fue cerrado en presencia del cuerpo consular, la comisión de jefes y oficiales, el gobernador, el vicegobernador, los ministros, los miembros del poder Judicial y Legislativo, las comisiones oficiales y su hijo Roberto Ortega. Sobre el ataúd fue colocado el sombrero y otras condecoraciones militares. Posteriormente, este fue retirado de la Casa de Gobierno por los familiares "1levándolo á pulso hasta la cureña de un cañón", mientras que en una gran carroza se depositaban las coronas de flores. El cortejo partió de la mencionada institución ubicada entre la intersección de las calles Rivadavia y Mitre, frente a la Plaza Independencia, ${ }^{19}$ luego continuaba por

${ }^{13}$ Diario La Tarde, 21 de noviembre de 1917, “Fallecimiento del Teniente General D. Rufino Ortega”, p. 4. Hacia 1914 la población de la actual Área Metropolitana de Mendoza alcanzaba a 157422, es decir, que el 3,8\% c. asistió al velorio (Tercer Censo Nacional de la República Argentina. (1916). Tomo 2, Buenos Aires: Talleres Gráficos de L. J. Roseo y Cía.).

14 Diario Los Andes, 22 de noviembre de 1917, "Teniente General Rufino Ortega”, p. 6.

${ }^{15}$ Diario Los Andes, 22 de noviembre de 1917, “Teniente General Rufino Ortega”, p. 6.

${ }^{16}$ Diario Los Andes, 21 de noviembre de 1917, "Teniente general Rufino Ortega", p. 6.

17 Digesto Municipal de la Capital. (1935). Recopilación de leyes, ordenanzas y decretos hasta febrero de 1935. Mendoza: Impresores Brest.

18 Diario Los Andes, 21 de noviembre de 1917, “Teniente general Rufino Ortega”, p. 6.

${ }^{19}$ Además, se encontraban otros edificios importantes: Tribunales y Policía (en la misma manzana que la Casa de Gobierno). Sobre calle Unión estaba la intendencia, la iglesia San Nicolás, el club social, el departamento de obras públicas (Verdaguer, 1933). Posteriormente, la Casa de Gobierno fue trasladada al actual predio, mientras que el terreno anterior fue ocupado por la Escuela Normal Mixta Tomás Godoy Cruz y las dependencias del ministerio de educación de la nación. 
la calle San Martín hasta llegar al cementerio público de la ciudad. ${ }^{20}$ Estos sitios constituían espacios de sociabilidad de la población mendocina, siendo, en el caso de la arteria San Martín, escenario del proceso de modernización (luz, actividad bancaria, tranway) y de vinculación entre la nueva y antigua ciudad (imagen 2) (Cirvini, s/f). ${ }^{21}$

Imagen 2. Plano de la ciudad de Mendoza a fines del siglo XIX

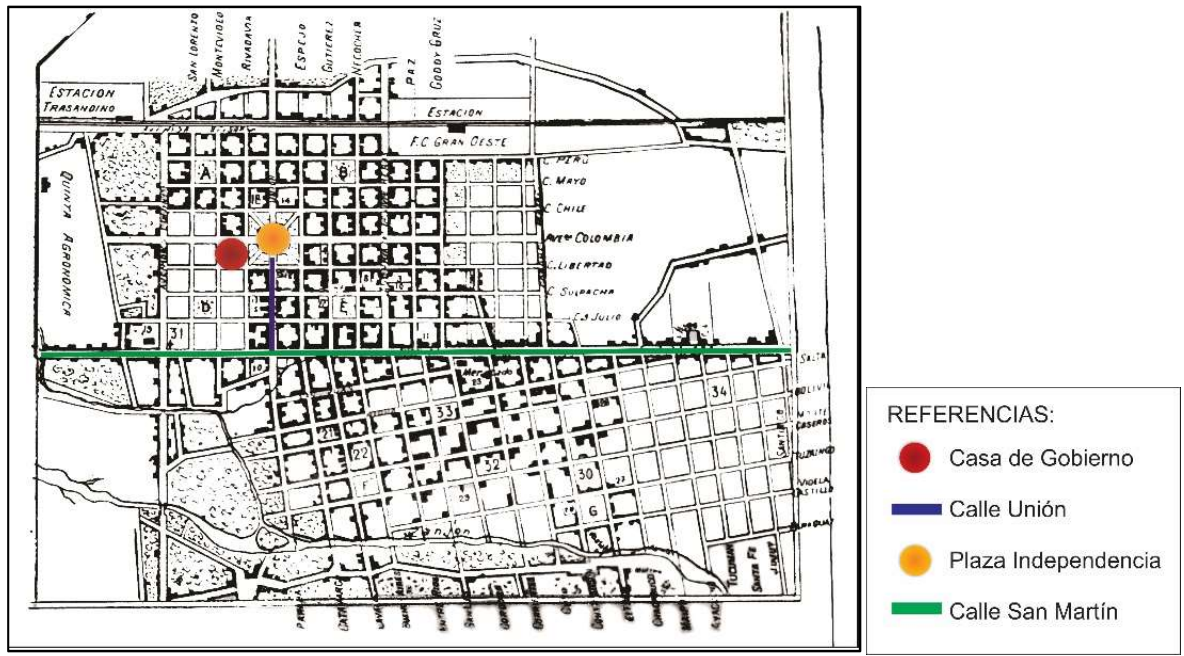

La procesión comenzó con el toque del clarín de la fanfarria del Escuadrón de Seguridad, que a su vez encabezaba el cortejo (imagen 3), luego continuaba la carroza y la cureña con el féretro. Tras este, los deudos, los miembros del Poder Ejecutivo y la policía, miembros del cuerpo consular, del poder Judicial y Legislativo, funcionarios públicos, corporaciones y una "gran masa de pueblo". ${ }^{22}$ De este modo, a través de estos funerales, el Estado delineaba la escala de la ceremonia y la importancia del sujeto homenajeado; además, era un recurso que le permitía distribuir poder político y determinar jerarquías sociales al pautar el lugar que debían ocupar los sujetos, los grupos y las autoridades tanto en el cortejo como luego, en el acto de inhumación por medio del orden de los oradores (Gayol, 2012, p. 7). Este rito "era un homenaje oficial al muerto y el inicio de un trabajo oficial de memoria, pero al mismo tiempo una oportunidad en la que el Estado daba muestras de su poder y presentaba la versión oficial del evento y de sí mismo. Para las elites en el Gobierno el desarrollo, los comentarios y la adhesión que suscitaban los funerales eran una prueba de su legitimidad y de la del régimen" (Gayol, 2012, p. 7). Una

\footnotetext{
${ }^{20}$ Diario La Tarde, 7 de junio de 1916, "Fallecimiento de don Carlos González" pp. 1-4.

${ }^{21}$ En 1861, Mendoza fue víctima de un terremoto que desató incendios, inundaciones y saqueos, con lo cual la ciudad colonial se vio totalmente destruida, con una gran pérdida material y humana. A partir de entonces, este sector comenzó a denominarse la "ciudad vieja"; no obstante, este corte abrupto permitió la conformación de la una "nueva ciudad", con un planteamiento "moderno y progresista", ubicado en la zona de San Nicolás, al sudoeste de la antigua (Ponte, 1999).

22 Diario Los Andes, 22 de noviembre de 1917, “Teniente General Rufino Ortega”, p. 6.
} 
vez llegado el séquito al cementerio, las bandas de Regimiento 16 de Infantería y la policía presentaron armas y prorrumpieron en marchas fúnebres. Entre los honores militares se dispuso que frente a la necrópolis se colocara el mencionado regimiento y una batería del primer grupo de Artillería de Montaña, ambas fracciones del ejército fuera con sus banderas y bandas respectivas. Conjuntamente, asistiría una comisión compuesta por los jefes de la guarnición para inhumar el cadáver y en dicho acto hizo uso de la palabra el mayor en representación del ejército nacional. ${ }^{23}$

Imagen 3. Cortejo de Rufino Ortega ${ }^{24}$

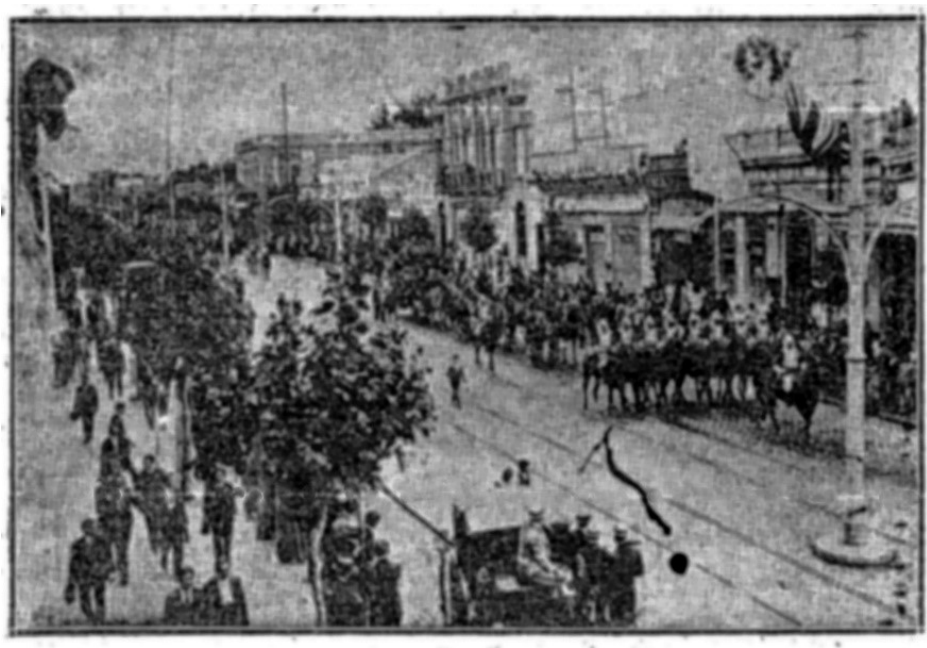

En el interior del establecimiento se realizaron los discursos de las distintas agrupaciones. Estas oraciones constituían un componente clave para la transformación del político en ancestro, estableciendo la relación entre la biografía del difunto y el régimen político, resaltando la trayectoria pública y, en especial, aquellos valores que ejemplificaban el régimen y se entrelazaban con su historia (Ben-Amos, 2007). De esta forma, el representante del Poder Ejecutivo, el entonces ministro de Industrias y Obras Públicas Dr. José A. Salas -quien había integrado el Consejo Provincial de Higiene durante la gobernación de Ortega-, destacó las principales normativas de dicha gestión, entre ellas, la ley de aguas ${ }^{25}$ y la sanción de la ley de registro civil, "exponente bien resaltante, por cierto, de las ideas liberales y de progreso que caracterizaron su laboriosa como honrada administración" ${ }^{26}$

\footnotetext{
${ }^{23}$ Diario Los Andes, 21 de noviembre de 1917, “Teniente general Rufino Ortega", p. 6.

${ }^{24}$ Diario Los Andes, 22 de noviembre de 1917, “Teniente General Rufino Ortega, p. 6.

${ }^{25}$ Esta ley otorgaba a los propietarios concesiones de riego para las tierras de cultivo y, según Mateu (2004), era empleado como recompensa política, beneficiando a las elites y a los inmigrantes que contaban con un cierto poder económico.

${ }^{26}$ Diario Los Andes, 22 de noviembre de 1917, “Teniente General Rufino Ortega”, p. 6.
} 
50 । Muerte y política: los funerales de Rufino Ortega...

Además, subrayó que estimuló "la demografía extranjera á que debemos en gran parte el impulso de nuestra principal industria, que tuvo también ese tiempo oportunidad de exhibirse en sus crecientes progresos"; extendió el ferrocarril hasta los Andes, lo que permitió "que ligaran definitivamente los pueblos de la república para el bien de su comercio, su industria y su grandeza y hasta la consolidación misma de nuestra propia nacionalidad". Se remarcaba entonces que en concordancia con las ideas de Roca "continúo con la obra civilizadora y de adelanto de los mas esclarecidos presidentes argenti$\operatorname{nos}(\mathrm{sic})^{\prime \prime} .{ }^{27}$

A continuación, el orador expresó que donde más se destaca su “acción como servidor del país y se pone más de relieve el temple [...] es analizando una por una sus acciones de guerra en que actuó como militar". De este modo, sus triunfos se manifestaban en "las medallas y condecoraciones de guerra que ostentaba en vida en sus uniformes de gala". A ello se sumaba su origen "de guerrero de reconocido mérito y de noble abolengo". También se destacaba su rol como comandante del Batallón 12 de Infantería y por el cual el pueblo de Mendoza debía recodarlo, ya que este formó parte de la $4^{a}$ división expedicionaria del desierto y "a cuyo sufrimiento, valor, peripecia y disciplina, debemos los habitantes de este tan prospero pueblo la desaparición de las viejas fronteras del sud, la extensión y dominio de todo el territorio de la provincia, como la extinción de las tribus salvajes que hiciere por tantos años precaria e insegura la existencia y la propiedad en los desiertos de su dominio o atropellos". ${ }^{28}$

Por último, el orador concluyó

[...] todos los momentos de su vida son, á mi juicio, digno ser evocados para ejemplo de pueblos y generaciones; y en la era presente, en que los buenos ciudadanos de la república empiezan a temer hasta por la estabilidad y respeto de las instituciones que rigen nuestro destinos como pueblo, yo quisiera que nos retorne nuestro postrer adiós ante su tumba, con esas bendiciones misteriosas de los muertos de su talla, que alientan la virtud cuando flaquea, las engerías, cuando fallecen, la perseverancia cuando desespera y el patriotismo cuando la patria está en el peligro (sic). ${ }^{29}$

El discurso pronunciado por Salas destacó la imagen de Ortega como militar y gobernador progresista que había colaborado en los avances en materia de industria y transporte, fomentado la inmigración y extensión de los límites de la provincia hacia el sur y sancionando leyes, como la de agua y registro civil. Así, estas ceremonias activaban el ejercicio de la memoria heroica, el recuento de los sucesos y hechos grandiosos, de las fatigas y penalidades sufridas, del sacrificio y las victorias justas (Rodríguez Jiménez, 2012). El orador también subrayó que este tipo de gobierno progresista se encontraba en peligro. Salas, en una carta -datada de fines del siglo XIX-dirigida a Roca, manifestaba

\footnotetext{
${ }^{27}$ Diario Los Andes, 22 de noviembre de 1917, “Teniente General Rufino Ortega”, p. 6.

28 Diario Los Andes, 22 de noviembre de 1917, “Teniente General Rufino Ortega”, p. 6.

${ }^{29}$ Diario Los Andes, 22 de noviembre de 1917, “Teniente General Rufino Ortega”, p. 6.
} 
su descontento con José Néstor Lencinas quien era el representante de la UCR a nivel provincial, considerándolo como el responsable de la violencia gestada en contra de los adversarios políticos (Lacoste, 1995). Los conservadores colocaron a los lencinistas en el lugar de la barbarie y los categorizaron como una "secta política" que practicaba "como sistema de gobierno el exterminio de sus adversarios, montonera sin ley, manifestación de la demagogia y la incultura política" (Persello, 2011, p. 129). La muerte de Ortega se producía en esta coyuntura política, en donde a los pocos días el poder Ejecutivo de la provincia fue intervenido por el radical Eufrasio Loza hasta febrero de 1918, bajo la orden del entonces presidente de la nación Hipólito Yrigoyen (Bragoni y Mellado, 2012).

Según los conservadores, esas intervenciones constituían "actos de violencia, de exclusivismo partidista, jalones en el camino de la unanimidad y en la construcción de un vasto imperio personal del presidente" (Persello, 2010, p. 82). Mientras que los radicales, tal como se mencionó, las consideraban necesarias y justas, ya que las autoridades habían sido elegidas de forma fraudulenta y era indispensable devolverle al pueblo la soberanía. No obstante, al año siguiente, en marzo de 1918, llegaría al poder, por vía constitucional, el radicalismo de la mano de José Néstor Lencinas quien fue proclamado gobernador. Lencinas era el representante de la "chusma ignorante y de la alpargata", en contraposición con Emilio Civit quien era el candidato del PAN. En un principio la figura de Ortega estuvo vinculada a los Civit, aunque tuvieron diferencias y tensiones, pero ambos pertenecían al PAN. Sin embargo, más allá de estas, uno de los designados por el partido conservador para velar el cadáver de Ortega fue precisamente Civit (Bragoni, 2006).

Así, el mencionado orador Salas, asociado a dicho régimen, establecía la relación entre la biografía del difunto y el partido político y la vinculación con los "gobiernos de familia", resaltando su carrera en la medida que ejemplificaba los valores del partido y se entrelazaba con la historia de estos gobiernos. A su vez, insistía en la pérdida de este tipo de regímenes y de la estabilidad de las instituciones estatales; lo que implicaba que la ceremonia fúnebre tuviera un carácter pedagógico (Ben-Amos, 2007).

Una vez concluidos los discursos, el ataúd fue colocado en el sepulcro perteneciente al político Joaquín Villanueva y se realizaron tres descargas por la infantería ${ }^{30}$. Estos honores, junto con "el acompañamiento en procesiones, las voces, las campanas, los cañones, pasaron a formar parte de la experiencia ritual de los nuevos funerales que se podrían considerar de Estado, recurso utilizado recurrentemente durante el proceso de consolidación de los Estados modernos" (Caretta, 2012, p. 111). Según McEvoy (2006, p. 28), la dirección de las ceremonias expresaba el "grado de penetración del Estado republicano y de sus mecanismos de control social en el espacio de la sociedad civil decimonónica".

${ }^{30}$ Diario Los Andes, 22 de noviembre de 1917, “Teniente General Rufino Ortega”, p. 6. 
Posteriormente, en 1925, los restos de Ortega fueron exhumados y trasladados al santuario de María Auxiliadora de Rodeo del Medio, ${ }^{31}$ a pesar de que esta práctica estaba prohibida desde $1845^{32}$. Para este acto, hicieron guardia de honor el Regimiento $16^{\circ}$ de Infantería, Cazadores de los Andes y un piquete del Regimiento $1^{\circ}$ de Artillería de Montaña, quien luego acompañó los restos hasta el límite de Ciudad. En Rodeo del Medio esperaba un numeroso público que rindió un "justo homenaje póstumo a este digno militar, quien en vida fundara [dicho] pueblo". ${ }^{33}$ En el templo se realizó una misa de cuerpo presente con cánticos sagrados y un "coro que armonizó sus notas al acorde de la orquesta", al cual asistieron los familiares, el interventor provincial, ${ }^{34}$ los altos funcionarios y los vecinos. Posteriormente, los restos fueron depositados en una cripta de mármol, cuya parte superior estaba coronada por una figura alegórica (imagen 4). Según Los Andes, el "acto dio lugar a una importante manifestación de duelo". ${ }^{35}$

\section{Imagen 4. Tumba de Rufino Ortega en el Santuario de María Auxiliadora ${ }^{36}$}

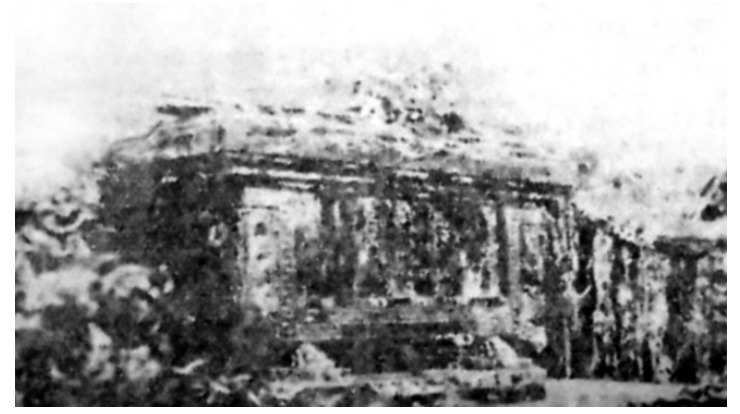

Probablemente, el traslado de los restos fue realizado por los familiares y esto se debió a que Ortega había mantenido un estrecho vínculo con la orden salesiana que estaba instalada en Rodeo del Medio desde 1901. Si bien la localidad existía desde hacía tiempo, el general junto con el salesiano Aquiles Pedrolini ${ }^{37}$ delinearon el trazado urbanístico en 1907, incluso uno de los padrinos del templo fue Ortega junto con su mujer, María Leonor Solanilla Tabanera, y el entonces gobernador Emilio Civit (Fresia, 2007). De acuerdo con Fresia (2005), los salesianos mantuvieron una "red de influencias" con integrantes

\footnotetext{
${ }^{31}$ Diario Los Andes, 8 de agosto de 1925, “Serán trasladados los restos del General Rufino Ortega”, p. 5.

32 AGPM, cementerios, carp. 199, doc. 10, 1845.

${ }_{33}$ Diario Los Andes, 11 de agosto de 1925, "Ayer fueron trasladados a Rodeo del Medio los restos del general Rufino Ortega", p. 4.

${ }^{34}$ En ese momento la provincia se encontraba intervenida por el gobierno nacional a través de Enrique Mosca, quien había desplazado a Carlos W. Lencinas.

${ }_{35}$ Diario Los Andes, 11 de agosto de 1925, "Ayer fueron trasladados a Rodeo del Medio los restos del general Rufino Ortega", p. 4.

${ }^{36}$ Diario Los Andes, 11 de agosto de 1925, "Ayer fueron trasladados a Rodeo del Medio los restos del general Rufino Ortega", p. 4.

${ }_{37}$ Pedrolini impulsó la creación del santuario de María Auxiliadora y fue el primer cura de la parroquia de Rodeo del Medio, además, fue director de la Escuela Vitivinícola (1905-1927) (Verdaguer, 1933). En el aniversario de muerte del general, Pedrolini realizó una ofrenda floral en sufragio por su alma (Fresia, 2012).
} 
de la elite, entre ellos los Ortega y Bombal, con el fin de promover el apoyo, la obtención de recursos y el sustento para llevar a cabo la acción pastoral.

En síntesis, se considera que el funeral de Ortega continuó con el protocolo que establecía el Estado provincial: velorio en la Casa de Gobierno, honores militares, discursos apoteóticos y honores civiles, como la bandera nacional izada a media asta y la serie de disparos. También se apeló a ritos católicos como la misa de cuerpo de presente en la sede del Poder Ejecutivo y el posterior entierro ad sanctos en el santuario de María Auxiliadora; estos gestos pusieron de manifiesto la ambigüedad en materia religiosa que poseía el Estado provincial. De tal forma, se puede observar que hubo una resistencia por parte de la elite a determinadas regulaciones implementadas por la institución estatal, al continuar con prácticas que fueron coaccionadas desde arriba por la Iglesia en su momento. Incluso, el traslado de los restos, constituyó un indicador del poder de dicho grupo y de la red de influencia que le permitía transgredir la reglamentación de cementerios vigente.

\section{El apóstol político: la muerte de José Néstor Lencinas}

En 1891, Lencinas, ${ }^{38}$ como se mencionó, comenzó a liderar el sector progresista de la UCR y se convirtió en su líder popular apoyado por Leandro Alem. No obstante, anteriormente había sido legislador provincial durante el conservadurismo y se vinculó con Rufino Ortega y Juárez Celman. Luego encabezó la Revolución de 1905, pero ante el fracaso a nivel nacional, tuvo que exiliarse en el vecino país de Chile. A pesar de ello, esta revuelta consiguió que hacia 1912 se aprobara la ley Sáenz Peña, lo que le permitió al partido participar del ámbito político dentro del marco legal. De este modo, Lencinas alcanzó la gobernación en 1918 y a partir de entonces el radicalismo fue el partido hegemónico hasta 1929, aunque sin concluir ningún mandato. ${ }^{39}$

Los estatutos de 1892 de la UCR -independientemente de la práctica- planteaban "conformar una agrupación permanente, principista e impersonal y establecer un gobierno descentralizado, dándole al partido una estructura federativa con base en los clubes" que se diferenciaba de los principios del PAN, basados en el personalismo y en la pertenencia a los círculos de notables, como ya se indicó. En consecuencia, comenzaban a circular ideas sobre cuál debía ser el nuevo perfil del actor político. Este debía vivir de la política y legitimar "su lugar en el cursus honorum en el interior de un partido" (Perse1lo, 2010, p. 73), en donde prevalecían los lazos de lealtad y la afiliación sobre la pertenecía al grupo. El radicalismo planteaban una serie de cambios que buscaban poner en vigencia un régimen democrático, "aunque inscripto en la propia legalidad oligarquía".

\footnotetext{
${ }^{38}$ Lencinas nació en 1959 en Mendoza. Provenía de una familia de ganaderos del sur de la provincia. Se casó con Fidela Peacock y tuvieron 6 hijos, entre ellos, Carlos W. Lencinas, quien también sería gobernador. ${ }^{39} \mathrm{El}$ primer triunfo fue la fórmula Lencinas- Álvarez; el segundo, en 1922, C. W. Lencinas - Gargantini y el tercero, en 1926, Orfila - Saá Zarandón, estas dos últimas bajo la denominación de UCRL (Lacoste, 1995).
} 
No obstante, este partido estaba integrado por grupos heterogéneos lo que generó una serie de tensiones y rupturas hacia el interior del mismo, tanto a nivel nacional como provincial $^{40}$.

Progresivamente, la Unión Cívica Radical Lencinista (UCRL) -que contaba con un amplio apoyo popular- se fue separando del yrigoyenismo para luego adherir a las filas del antipersonalismo, aunque sin el apoyo pleno de sus bases (Persello, 2010). De este modo, durante el mandato de Lencinas, la provincia fue intervenida por el Gobierno nacional en dos oportunidades: una primera, desde noviembre de 1918 hasta abril de 1919 a cargo de Tomás Veyga y una segunda, desde abril hasta junio del mismo año por Perfecto Araya. En junio de ese año reasumió Lencinas y en enero de 1920 falleció.

Los motivos de estas intervenciones fueron múltiples, entre ellos, los conflictos que se generaron con los maestros por la represión a una huelga, con la Compañía Vitivinícola de Mendoza por su intervención y con el vicegobernador Delfín Álvarez por vetar una ley que disponía otorgar de un sueldo a los legisladores. Este último conflicto fue el detonante que a su vez provocó la división interna del radicalismo mendocino, entre UCRL y la UCR disidente o intransigente. ${ }^{41}$

En medio de este clima de tensión, en enero de 1920, comenzó a circular la noticia de que el estado de salud del entonces gobernador era crítico, "temiéndose un desenlace fatal" y a las horas se anunció su muerte por medio de un toque de sirena. ${ }^{42}$ Su defunción fue lo que se consideraba por ese entonces una buena muerte: "rápida, serena, en medio del amor de los suyos y del cariño de su pueblo, que lo aclamó hasta el morir". Lencinas fue auxiliado desde el primer momento por el reverendo franciscano Duraro, quien atendió al moribundo desde su enfermedad hasta su muerte. Momentos antes de morir, "hizo llamar a un núcleo de sus amigos, y aunque fatigosamente, pudo decirles sus impresiones, sus deseos y su último pensamiento", encomendó "la obra que se ha venido realizando y que, sobre todo, no olvidasen de lo que él solía decir 'mis pobres'”. ${ }^{43}$ Lencinas quería reformular las prácticas políticas hasta entonces vigente, con el “objetivo de

\footnotetext{
${ }^{40}$ Leandro Alem -inscripto en la tradición "liberal" - consideraba que el partido debía ser impersonal y defendía la libertad del individuo frente a la intervención excesiva del Estado, al igual que la autonomía de las provincias. Planteaba que "el orden legítimo era aquel limitaba el poder, dividiéndolo y descentralizándolo". Por su parte, Hipólito Yrigoyen se centraba en la construcción de la nación "como instancia privilegiada de articulación posibilitando la síntesis y agregación del conjunto social”. Así, el partido iba construyéndose como una fuerza que pretendía monopolizar la construcción de la nación misión histórica del radicalismo-, siendo esta la primera tensión que derivó en los conflictos internos. Allí, en 1924, se fundó la división del partido entre aquellos que adherían a los principios fundadores de Alem los antipersonalista-y aquellos que apoyaban a Yrigoyen -los personalistas- (Persello, 2010, pp. 67-68). ${ }^{41}$ Para profundizar en este tema, ver: Olguín (1965); Lacoste (1995).

42 Diario Los Andes, 21 de enero de 1920, “El fallecimiento del gobernador de la provincia José Néstor Lencinas", p. 3.

${ }^{43}$ Diario La Palabra, 21 de enero de 1920, “La muerte del gobernador de la Provincia Doctor José Néstor Lencinas", p. 1.
} 
asegurar la influencia de la élite ilustrada en detrimento de las bases populares" (Lacoste, 1995, p. 32). Por ello, el programa de este partido "basaba su soporte popular en su discurso antioligárquico y para reforzar su imagen antioligárquica se presentaba la alpargata como el símbolo del partido" (Satlari, 2004, p. 302), con el fin de reivindicar la voluntad popular como fuente de poder.

Ante la muerte del gobernador, se instaló en un salón de la vivienda particular la capilla ardiente decorada con cirios y candelabros, custodiada por un piquete de guardia del cuerpo de bomberos vestidos de gala. A diferencia de Ortega, el cadáver estaba amortajado con un sencillo traje negro y entre las manos se entrelazaba la banda insignia de primer mandatario (imagen 5). Al velorio privado asistieron damas de la sociedad mendocina, ministros, representantes del poder Ejecutivo, Legislativo y Judicial, y altos empleados de la administración pública. ${ }^{44}$ No obstante, también lo hizo una gran muchedumbre, que según la prensa, se encontraba impaciente por ingresar al domicilio para homenajear al "cuerpo yacente" de su gobernante. ${ }^{45}$ Allí mismo tuvo lugar una misa de cuerpo presente. Luego de la ceremonia, un piquete de cuerpo de bomberos y de policía -uniformados de gala- rindieron los honores correspondientes. ${ }^{46}$

\section{Imagen 5. Capilla ardiente en la vivienda particular ${ }^{47}$}

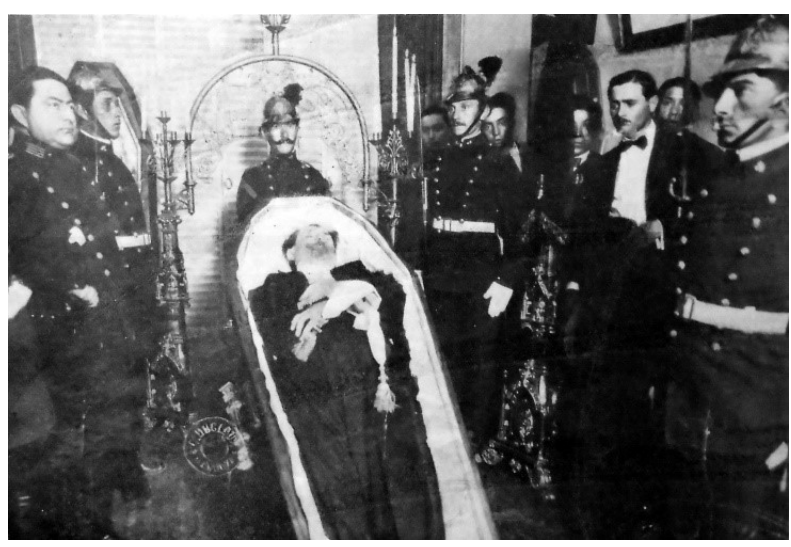

Ante la noticia, el presidente del senado de la provincia -en ejercicio del Poder Ejecutivo- dictó un decreto en acuerdo con los ministros:

\footnotetext{
${ }_{44}$ Diario Los Andes, 21 de enero de 1920, “El fallecimiento del gobernador de la provincia José Néstor Lencinas", p. 3.

45 Diario La Palabra, 21 de enero de 1920, “La muerte del gobernador de la Provincia Doctor José Néstor Lencinas", p. 1; Diario Los Andes, 21 de enero de 1920, “El fallecimiento del gobernador de la provincia José Néstor Lencinas", p. 3.

46 Diario Los Andes, 22 de enero de 1920, "El fallecimiento del gobernador de la provincia", p. 3.

${ }^{47}$ Revista La Quincena Social, 15 al 30 de enero de 1920, "Las diversas expresiones de duelo", s/p.
} 
Habiendo fallecido en la fecha S. E. gobernador de la provincia, Dr. José Néstor Lencinas, y considerando: Que en trance tan doloroso e irremediable es un deber primordial del gobierno honrar a la persona y la memoria de su primer mandatario como entidad representativa de la soberanía de la provincia [...]. Que la desaparición del Dr. José Néstor Lencinas constituye además de un duelo público, toda una desgracia irreparable para el pueblo de su provincia al cual había consagrado íntegros sus afanes, las aspiraciones de toda su existencia, logrando por dicha causa obtener sus simpatías y su cariño, en una forma tal que su muerte lo ha llenado de consternación. ${ }^{48}$

Por lo tanto, a los honores que correspondían al cargo de gobernador ${ }^{49}$ tal como se vio con Ortega, se sumaron otros, como declarar los días 21 y 22 de enero feriados con el fin de que "todo el pueblo" asistiera al funeral; al igual que sucedió durante las ceremonias fúnebres del centenario analizadas por Gayol (2012). Este decreto permitió que todo trabajador pudiera asistir a la inhumación de su líder político, otorgándole un rol protagónico y fundamental a este sector, ya que desde la asunción de Lencinas al cargo de gobernador, uno de sus objetivos fue mantener una relación estrecha con las masas (Rodríguez, 1979).

Otro honor acordado fue el envío de una corona de flores naturales y la bandera nacional para que fueran colocadas sobre el ataúd. También determinaron que los gastos causados por la enfermedad e inhumación fueran cubiertos por el gobierno provincial. Por su parte, la Corte Suprema de Justicia dispuso que la bandera nacional debía permanecer izada a media asta en todos los edificios dependientes de su administración durante diez días y designaba una comisión de magistrados para velar el cadáver y un vocero para que hiciera uso de la palabra en el acto de inhumación. ${ }^{50}$

De igual modo, la Cámara de Diputados adhirió al duelo nombrando una comisión para que asistiera al velorio, asignó un representante para que dijera unas palabras alusivas en el entierro e invitó a los señores diputados para que acompañaran los restos. Enviaba, además, una corona de flores naturales y una placa de bronce para que fuera colocada en la tumba junto con una nota de pésame a la familia. No obstante, en sesión ordinaria de la cámara, treinta y uno de sesenta diputados decidieron no rendir el honor correspondiente que consistía en ponerse de pie (Olguín, 1965). Esto se debía a la convulsionada situación política y social que se encontraba atravesando la provincia por los

48 Diario Los Andes, 21 de enero de 1920, “El fallecimiento del gobernador de la provincia José Néstor Lencinas", p. 3.

${ }^{49} \mathrm{Al}$ igual que el cuerpo de Ortega, el de Lencinas sería traslado al salón de recepciones de la Casa de Gobierno - "transportado a pulso [...] por sus hijos Carlos W., José H. y Rafael y los ex ministros Dr. Carlos Puebla, Ing. Leopoldo Suarez y Antonio Soriano"- (Revista La Quincena Social, 15 al 30 de enero de 1920 "Las diversas expresiones de duelo", s/p), en donde se montaría otra capilla ardiente con numerosos cirios, candelabros y coronas de flores, y sería velado por una comisión integrada por senadores, diputados provinciales y miembros del poder Judicial (Diario Los Andes, 21 de enero de 1920, El fallecimiento del gobernador de la provincia José Néstor Lencinas, p. 3).

50 Diario Los Andes, 21 de enero de 1920, “El fallecimiento del gobernador de la provincia José Néstor Lencinas", p. 3.

Anuario de la Escuela de Historia Virtual - Año 9 - N 13 - 2018: pp. 42-66. ISSN 1853-7049 
mencionados conflictos con los maestros, la Compañía Vitivinícola y el vicegobernador. Ante este clima de tensión, la cámara de diputados de la nación quiso nombrar una comisión para que investigara la situación y frente a ello Lencinas lanzó un decreto para impedir dicho accionar. Varios legisladores radicales se opusieron al gobernador y se aliaron a los conservadores y, probablemente, por ello, no rindieron el homenaje correspondiente (Olguín, 1965). ${ }^{51}$

Por su parte, el Senado de la provincia y la Municipalidad de Ciudad rindieron honores similares a los de la Cámara de Diputados y esta última institución sumó la orden de suspensión de los espectáculos públicos. ${ }^{52}$ Por otro lado, el gobierno nacional exponía sus manifestaciones de duelo a través del izamiento a media asta de la bandera nacional en los edificios públicos, los buques de armada y las fortalezas, además, de los honores militares correspondientes. ${ }^{53}$ Otras instituciones que también realizaron homenajes fueron los gobiernos provinciales de La Rioja y Catamarca, el Consejo de Educación, la Unión Mendocina de Maestros, los Exploradores de Don Bosco, el Centro de Viticultores Enólogos, la Municipalidad de Godoy Cruz, el club de Gimnasia y Esgrima, el Aéreo Club Mendoza, el comité de la Juventud y la Unión Comercial e Industrial. Esta última entidad solicitó al comercio que cerrara los negocios durante el sepelio. ${ }^{54}$

Luego del velorio en el domicilio particular, los restos fueron conducidos a la Casa de Gobierno y, posteriormente, a la iglesia de San Francisco, en donde se ofició una misa de cuerpo presente (a pesar de estar prohibida desde 1896 como se mencionó), la cual fue anunciada en el aviso fúnebre solicitado por la UCR. Según Gayol (2012), esta práctica fue común en los funerales de los presidentes que fallecieron entre fines del siglo XIX y principios del XX. Durante la procesión, el féretro fue acompañado por los hijos del difunto, el gobernador provisorio Ricardo Báez y los exministros. ${ }^{55}$ Pero no solo se encontraban miembros del poder estatal, sino también religioso, como un franciscano y probablemente un mercedario, los cuales encabezaron la procesión (imagen 6). Allí, el cuerpo de bomberos rindió los homenajes correspondientes.

\footnotetext{
${ }^{51}$ Quiero agradecer a la Lic. Natalia Luis por facilitarme bibliografía sobre lencinismo.

${ }^{52}$ Diario Los Andes, 21 de enero de 1920, “El fallecimiento del gobernador de la provincia José Néstor Lencinas", p. 3.

53 Diario Los Andes, 22 de enero de 1920, "El fallecimiento del gobernador de la provincia”, p. 3.

${ }^{54}$ Diario Los Andes, 22 de enero de 1920, "El fallecimiento del gobernador de la provincia", p. 3.

${ }^{55}$ Revista La Quincena Social, 15 al 30 de enero de 1920, "Las diversas expresiones de duelo", s/p.
} 


\section{Imagen 6. Traslado del féretro de la Casa de Gobierno a la iglesia de San Francisco ${ }^{56}$}

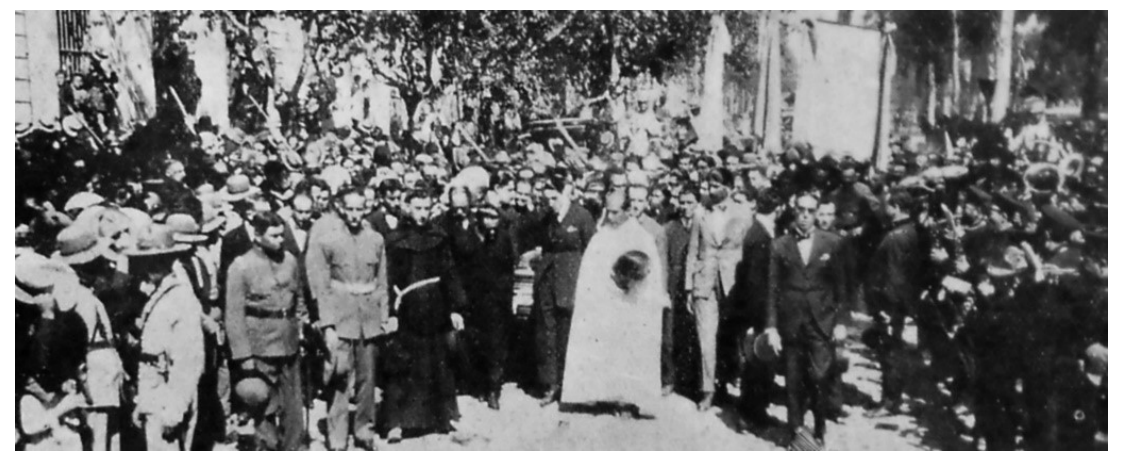

Según destacó la prensa, el pueblo ocupó un rol protagónico en las diferentes instancias del funeral ya que era el participante habitual de este tipo de ceremonias (García Ferrari y Gayol, 2015). De tal forma, manifestaba que el público "fluyó incesantemente [en la Casa de Gobierno] desde las últimas horas de la mañana hasta después de medianoche, en que solo quedaron las comisiones encargadas de velar el cadáver" ${ }^{27}$ Lo mismo ocurrió durante el cortejo (imagen 7) y en el acto de inhumación en el cementerio de Ciudad. De este modo,

el pueblo llora a su gobernante y a su conductor. En la calle se miran unos a otros contristados; se forman corrillos; el pueblo desfila por el domicilio del extinto; hablan por teléfono con emoción en la voz los que preguntan la confirmación del triste suceso o quieren conocer particularidades de él. Y es este dolor popular, el interés público despertado por la muerte del hombre, la suprema consagración de los espíritus superiores. ${ }^{58}$

\footnotetext{
56 Revista La Quincena Social, 15 al 30 de enero de 1920, “Las diversas expresiones de duelo", s/p.

${ }^{57}$ Diario Los Andes, 22 de enero de 1920, “El fallecimiento del gobernador de la provincia”, p. 3.

58 Diario La Palabra, 21 de enero de 1920, “La muerte del gobernador de la Provincia Doctor José Néstor Lencinas", p. 1.
} 


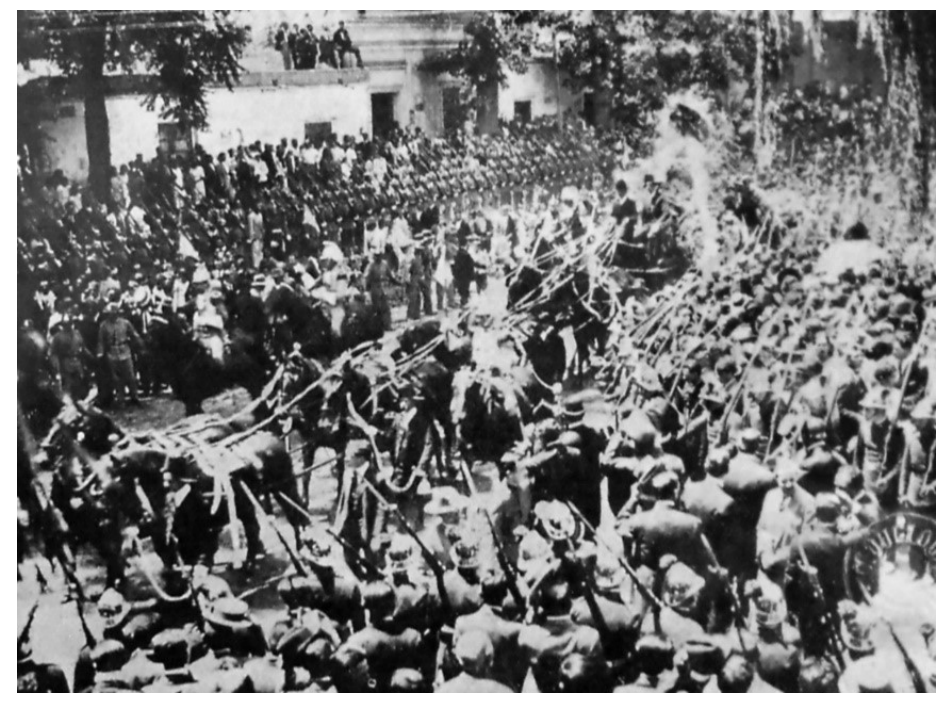

En este sentido, el cuerpo de Lencinas fue eficaz tanto para la acuñación de la identidad de grandes grupos, como para la articulación y el reforzamiento de reivindicaciones políticas (Rader, 2006). Este ritual constituyó un elemento más de fortalecimiento de la autoridad y legitimidad del poder radical mendocino. Como plantea Gayol (2013), la importancia de la multitud en los funerales recaía en diversos aspectos dependiendo de quién era el muerto, de su trayectoria y los rituales fúnebres desplegados, de la coyuntura política en la cual se producía el deceso y de cómo este "recurso" era apropiado por las elites gobernantes.

Se considera que en la ceremonia de Lencinas la "muchedumbre", el "pueblo" cumplió un rol destacado o al menos eso intentó demostrar el partido, ya que este constituía el sector social al cual los gobiernos lencinistas buscaban favorecer a través de sus políticas sociales. Reyes explica que estas ceremonias, así como los actos conmemorativos como los de la Revolución del Parque- proporcionaron al radicalismo de un carácter popular porque eran "verdaderas demostraciones multitudinarias de fuerza, las cuales comenzaron a prefigurar ciertas formas típicas de la política de masas". Además, constituyeron un espacio privilegiado "en el cual se desplegaron los símbolos, sentidos y las figuras idealizadas de una identidad" (Reyes, 2016, p. 44).

Antes de la muerte de Lencinas, los radicales mendocinos ya divulgaban una imagen de él con aspectos extrahumanos; estas voces fueron "eco de las aspiraciones de la gente humilde, y aunque llenas de vaguedades, se expresaban casi con veneración religiosa" (Rodríguez, 1979, p. 54). Después de su deceso, esta imagen continuó acentuándose,

${ }^{59}$ Revista La Quincena Social, 15 al 30 de enero de 1920, “Las diversas expresiones de duelo”, s/p. 
60 I Muerte y política: los funerales de Rufino Ortega...

como se puso de manifiesto en el diario oficialista de la época con títulos, como "solemnemente fue ayer recordado en toda la provincia el $6^{\circ}$ aniversario del fallecimiento del inmortal patricio Dr. José Néstor Lencinas" o "la peregrinación a la tumba del apóstol" .60 Según McEvoy (2006), los funerales de Estado -en la actual América Latina- no estaban desprovistos de una dimensión religiosa, ya que el republicanismo no implicó una ceremonia cívico-secular excluyente debido a su ambigüedad en dicha materia. Así, los rasgos cívicos se articulaban con los religiosos, como sucedió en la repatriación de los restos de O'Higgins en 1869 (McEvoy, 2006). Estas ceremonias se encontraban impregnadas de un carácter católico que se manifestaba en los actos y objetos simbólicos seleccionados, por ejemplo cirios, crucifijos, oraciones y responsos.

Ya entonces, en vida de Lencinas, se construyó un mito acerca del lencinismo que perduró después de su muerte. Según Olguín (1965), no se supo si los hechos protagonizados por él fueron reales o estuvieron creados por la imaginación de sus simpatizantes o enemigos. En este sentido, como todo personaje visto a través de la pasión, su imagen se enalteció o despreció, "fue gigante o pigmeo, ángel o demonio, apóstol o bandido" (Olguín, 1965, p. 4). ${ }^{61}$ Pero luego de su muerte, los sectores más vulnerables continuaron asociando la imagen de Lencinas con un "dios tutelar", "desde su existencia invisible protegió a los menesterosos, alentó a los angustiados, ganó combates contra la injusticia y orientó a la chusma en la "vía crucis" de su liberación" (Olguín, 1965, p. 8). Este mito fue apoyado desde la jerga partidaria, quien denominaba a su líder como un apóstol que ejercía una marcada influencia sobre la gente que buscaba su consejo y ayuda, este paternalismo fue fruto de su convencimiento de que interpretaba cabalmente las necesidades e inquietudes de la gente común (Rodríguez, 1979). Según Reyes, dicha identidad “difícilmente hubiera podido adquirir esa potencia en el imaginario colectivo si el mismo hecho conmemorativo -y las imágenes allí construidas- no hubieran sido admirados como una gran acontecimiento por parte de sus simpatizantes, pero también si sus adversarios no le reconocieran una significación excluyente" (Reyes, 2016, p. 44).

Por otra parte, la tumba ${ }^{62}$ de Lencinas se convirtió en un santuario cívico y lugar de peregrinación para el pueblo (imagen 8). En uno de los aniversarios, el presidente del Comité de Capital de la UCR, Roberto Rinci, pronunció un discurso en honor a la memoria del difunto, al que asistió una gran cantidad de personas y agrupaciones, entre

\footnotetext{
60 Diario La Palabra, 21 de enero de 1926, "Solemnemente fue ayer recordado en toda la provincia el $6^{\circ}$ aniversario del fallecimiento del inmortal patricio Dr. José Néstor Lencinas", p. 1.

${ }^{61}$ Según Casquete (2007), la construcción social del mito político no necesariamente coincide con los hechos históricos, de este modo, las elites, encargadas de darle forma y cargarlos de contenidos, los moldean de acuerdo a sus necesidades e intereses.

${ }^{62}$ Los restos de Lencinas fueron inhumados en la tumba del bodeguero Rito Baquero en el cementerio público de Ciudad, luego, fueron trasladados a su capilla privada, ya en 1922 la municipalidad donó un terreno para que se construyera el actual sepulcro (Digesto Municipal de la Capital. (1935). Recopilación de leyes, ordenanzas y decretos hasta febrero de 1935. Mendoza: Impresores Brest).
} 
ellos, el "Comité Obrero Sección 3", tal como se observa en la fotografía (imagen 8). ${ }^{63}$ De este modo, el sepulcro fue un lugar de reunión y su visita formó parte del calendario partidario, en donde los sujetos asistían para comunicarse con sus padres fundadores y celebrar los valores compartidos (Ben-Amos, 2007), por lo que se transformó en un punto de referencia de un grupo social que necesitaba un recuerdo creador de identidad colectiva (Rader, 2006).

\section{Imagen 8. Tumba de Lencinas decorada para su aniversario ${ }^{64}$}

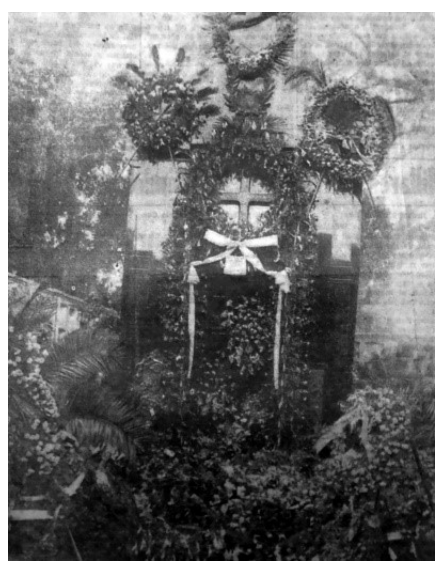

La tumba de Lencinas se convirtió en un lugar material, simbólico y funcional, en donde confluyó una historia de la población y de los individuos como seres sociales y culturales (Nora, 2008). Una evidencia de ello es que en el sepulcro se colocaron multiplicidad de placas conmemorativas, estas representaban: el escudo nacional y otros símbolos patrios, sujetos trabajando la tierra y en la industria, un anciano, una mujer con un niño. En una de ellas se leía la inscripción "la jornada de 8 horas, el salario mínimo, la caja de pensión a la vejez e invalidez ${ }^{65}$ y la reglamentación del trabajo de la mujer y el niño" (imagen 9), dando cuenta de los logros conseguidos por el lencinismo en materia social (Richard Jorba, 2013). Por lo tanto, la tumba se consolidó como espacio de memoria, al transformarse en objeto de ritual y veneración y manifestar el carácter "estelar o celestial" del homenajeado frente al común del ciudadano (Bragoni, 2013). Según Lomnitz (2006), a medida que se consolidaba el dominio estatal sobre los muertos y la historia nacional, la importancia y utilidad del dominio local sobre los cuerpos iba en aumento, y comenzó a asemejarse a la política respecto a los restos de los santos durante el periodo colonial.

\footnotetext{
${ }^{63}$ Revista La Quincena Social, 15 al 30 de enero de 1923, “En memoria del ex gobernador Dr. José Néstor Lencinas", s/p; Diario Los Andes, 19 de enero de 1932, “Organizase un funeral cívico de homenaje a la memoria del Dr. José Nestór Lencinas", p. 5.

${ }^{64}$ Diario La Palabra, 20 de enero de 1934, "El funeral de esta mañana”, p. 1.

${ }^{65}$ Esta ley fue aprobada durante la gobernación de Carlos W. Lencinas, aunque el proyecto fue de José N. Lencinas (Rodríguez, 1979).
} 


\section{Imagen 9. Placa colocada en la tumba de Lencinas en su honor (cementerio público de la ciudad)}

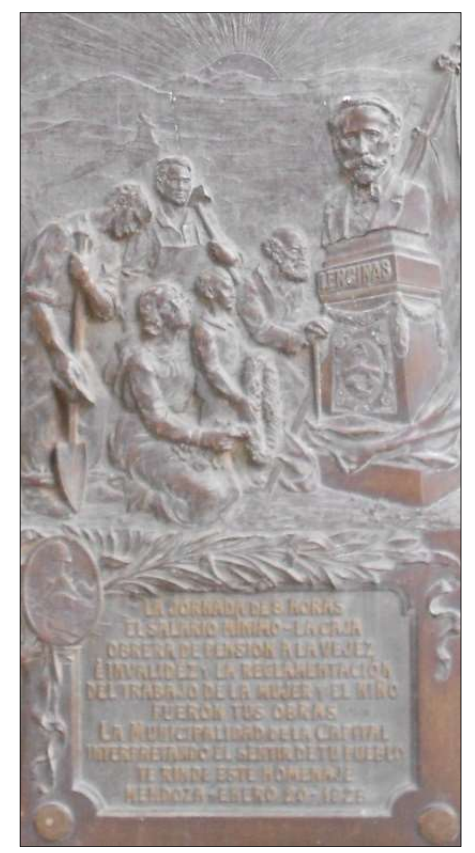

Por consiguiente, estos funerales fueron ceremonias públicas cargadas de contenidos y fórmulas estereotipadas, cuyos elementos como la música, las oraciones, los discursos y la participación de las autoridades, configuraron un espacio simbólico que articulaban el recogimiento con el sentimiento patrio (Mazzeo, 2006), lo cual permitió mantener latente la imagen de "padre fundador" del lencinismo. De este modo, los dispositivos que se emplearon para la ceremonia contribuyeron a la identidad partidaria. Según Reyes, para el caso de los actos conmemorativos de la Revolución del Parque y del funeral de Alem, tanto las notas editoriales de los órganos oficialistas como los discursos de los agentes en el cementerio expresaban una "serie de ideas-fuerzas, de figuras tipificadas, en suma, un lenguaje codificado propio del imaginario político de los radicales, santo y seña de una potente identidad en constitución" (Reyes, 2016, p. 67).

Luego de la muerte de Lencinas, fueron numerosos los actos conmemorativos que se realizaron en su honor. En los aniversarios se celebraban "funerales religiosos" en diferentes iglesias de la provincia, en los cuales la prensa destacaba la asistencia de miles de personas. ${ }^{66}$ Estos permitieron continuar revindicando la memoria de Lencinas y la construcción de la historia de dicha fracción. Como plantea Reyes (2016), los funerales y las

${ }^{66}$ Diario Los Andes, 19 de enero de 1932, “Organizase un funeral cívico de homenaje a la memoria del Dr. José Nestór Lencinas", p. 5; Diario La Palabra, 20 de enero de 1926, “El funeral cívico de esta noche”, p. 2; Diario La Palabra, 21 de enero de 1926, "Solemnemente fue ayer recordado en toda la provincia el $6^{\circ}$ 
conmemoraciones de fechas significativas y actores importantes ocuparon un lugar destacado en el radicalismo.

\section{Consideraciones finales}

Se ha podido observar a lo largo de este artículo que los funerales de los exgobernadores Rufino Ortega y José Néstor Lencinas tuvieron transcendencia en el ámbito político. Estos manifestaron las transformaciones que se gestaron en dicha esfera en el transcurso del siglo XIX al XX, marcadas por la democratización política y social. Este tipo de cultos formaron parte de una tendencia más amplia que había comenzado a instalarse en la Argentina desde la década de 1880 y que dio cuenta de la riqueza y la complejidad de un período clave en la construcción de las modernas identidades partidarias.

Estas ceremonias fueron ritos de pasaje y también herramientas pedagógicas a través de las cuales los gobiernos de turno buscaron resaltar los valores del partido en el cual estos sujetos habían militado y, de este modo, acentuar la identidad y legitimar las políticas del gobierno. Así, en el funeral de Ortega se destacaron los principios y avances progresistas de los gobiernos conversadores y con la muerte de Lencinas, las bases del radicalismo y sus políticas populistas; esto, en una coyuntura inestable que culminó con el golpe de Estado del 30.

Ambas muertes se produjeron en un momento de tensión entre fuerzas opositoras: por un lado, los conservadores y, por otro, los radicales; pero también hacia el interior mismo de la UCR entre los personalistas y antipersonalistas, a nivel nacional, y los lencinistas y los intransigentes, a nivel provincial. De este modo, los dispositivos, los símbolos, los ritos y las palabras que se emplearon en estas ceremonias funcionaron para asentar los valores y la identidad de estas fuerzas opositoras.

Sin embargo, estas ceremonias tuvieron un tratamiento similar porque adquirieron un carácter público cuando el cuerpo era trasladado por las calles de la ciudad a la Casa de Gobierno para efectuar el velorio en el escenario efímero de la capilla ardiente. El Estado tenía un control sobre el espacio público, el cual era acondicionado y decorado para la ocasión y, por lo tanto, modificaba el entorno habitual de los ciudadanos, además de que en él se diseñaba el trayecto que debía seguir el cortejo junto al féretro.

En la sede del poder provincial era colocado el cadáver en el centro de la escena, custodiado y homenajeado por las fuerzas provinciales y nacionales, mientras que el gobierno disponía de una serie de honores que consistían en la bandera nacional izada a media asta en los edificios públicos, el envío de coronas de flores y las cartas de pésame a los familiares. Los rituales no solo recibían un tratamiento secular sino también religioso: se realizó la misa de cuerpo presente en honor a Ortega en la Casa de Gobierno y

aniversario del fallecimiento del inmortal patricio José Néstor Lencinas", p. 1; Diario La Palabra, 21 de enero de 1928, "Hermosos contornos obtuvo el funeral cívico realizado anoche en el teatro municipal”, p. 5. 
hubo participación destacada del clero regular en el séquito. Por ello, se considera que estos ritos constituyeron ceremonias civiles con un halo sacro.

Otro aspecto fundamental de estos funerales eran los séquitos organizados jerárquicamente por el Estado, que se encargaba de acomodar en diversos sectores a las autoridades políticas y religiosas, los familiares y la "multitud". Así, pautaba la ubicación de los participantes durante las diferentes instancias de la ceremonia, lo que le permitía distribuir y reproducir jerarquías sociales. Un lugar destacado ocupó el "pueblo", la "masa", la "muchedumbre" -de todos los estratos sociales, grupos etarios y sexos-, cuya presencia garantizaba y legitimaba el ritual. La prensa recalcaba la gran cantidad de personas que asistía a estos funerales y, en este sentido, es notable que en el de Lencinas hubo una participación masiva que constituyó un elemento fundamental para construir su imagen como la de un "santo" popular y coronó, así, el relato de una acción política destinada al "pueblo".

Otro momento clave de estas ceremonias fue el de las oraciones durante el acto de inhumación en el cementerio público, en donde homenajearon a los exgobernadores y destacaron las virtudes cívicas y los logros de la gestión pública en busca de legitimar el gobierno de turno o acentuar un mensaje político. De este modo, a estos ritos se les asignaba un carácter pedagógico. Tal fue el caso de Ortega y Lencinas en los que se puso énfasis en la imagen de sus líderes políticos como representantes de fracciones opuestas. En el caso de Lencinas, en las oraciones también se empleaban categorías provenientes del ámbito religioso con el fin de otorgarles una connotación espiritual vinculada con Dios, los santos y los mártires. Se producía, así, una sacralización del político por medio de un respaldo religioso que contribuyó a su mitificación y a la construcción de su imagen como "padre fundador" del partido.

Los restos de los dos fueron sepultados en capillas privadas, por cuanto no había un panteón destinado a los exgobernadores, a pesar de lo que estipulaba la normativa estatal. Esto no impidió que se convirtieran espacios de memoria de la población ni que se transformaran, en el caso de Lencinas, en lugar de veneración y peregrinación en donde asistía la población para rezar y hacer sus pedidos al "santo protector".

Finalmente, se puede concluir que estos funerales fueron parte esencial de la cultura política mendocina, ya que contribuyeron a la construcción de una memoria colectiva que intentaba dar legitimidad a los regímenes políticos durante una coyuntura marcada por la inestabilidad.

\section{Referencias bibliográficas}

Ben-Amos, A. (2000). Funerals, Politics, and Memory in Modern France, 1789-1986. Oxford: Oxford University Press.

Ben-Amos, A. (2007). El centro sagrado del poder: París y los funerales de Estado republicanos. Culturales, 3 (6), 49-74. 
65 I Rosana Aguerregaray Castiglione

Bragoni, B. (2006). Breve historia de Mendoza. Recuperado de:

https://issuu.com/melisaardisana/docs/historiamendozabragoni (03/03/2017).

Bragoni, B. (2013). Rituales mortuorios y ceremonial cívico. José de San Martín en el panteón argentino. Histórica, 37 (2), 47-109.

Bragoni, B. y Mellado, V. (2012). Civitismo y lencinismo en Mendoza: prensa y elecciones, 1916-1918. Ponencia presentada en VIII Jornadas Historia Política. IEHS- UNICEN: Tandil.

Caretta, G. (2012). Ciudades de muertos y funerales de Estado. Paradojas en la reconstrucción de la religión y la política entre los Borbones y los gobiernos provinciales. En V. Ayrolo, M. E. Barral y R. Di Stefano (Coords.), Catolicismo y Secularización. Argentina, primera mitad del siglo XIX (pp. 93-113). Buenos Aires: Biblos.

Casquete, J. (2007). Religiones políticas y héroes patrios. Papers, (84), 129-138.

Cirvini, S. (s/f). Sitios con historia: la Avenida San Martín. Mendoza: mimeo.

Fresia, I. (2012). Urbanizar la campaña, modernizar las costumbres. Rodeo del Medio, una villa mendocina: 1900-1915. Rosario: Prohistoria.

Fresia, I. (2007). Impreso y prácticas de sociabilidad religiosa. Cultura popular y espacio público en la campaña mendocina, 1907-1915. Ponencia presentada en XI Jornadas Interescuelas/Departamentos de Historia. UNT: Tucumán.

Fresia, I. (2005). Religión, educación y vida cotidiana en Rodeo del Medio, siglo XX. Buenos Aires: Dunken.

García Ferrari, M. y Gayol, S. (2015). Ramón Falcón: asesinato político y usos políticos de la muerte. En S. Gayol y G. Kessler (Comps.), Muerte, política y sociedad en la Argentina Moderna (pp. 61-83). Buenos Aires: Edhasa.

García Garino, G. (2017). "El más alto poder". Legislatura y cultura política en el proceso de construcción del Estado provincial de Mendoza, 1852-1881 (Tesis de Doctorado). Facultad de Filosofía y Letras, UBA, Buenos Aires: mimeo.

Gayol, S. (2012). La celebración de los grandes hombres: funerales gloriosos y carreras post mortem en Argentina. Quinto Sol, 16 (2), 1-29.

Gayol, S. (2013). Ritual fúnebre y manifestación política en la Argentina de los años treinta. PolHis, (12), 225-244.

Lacoste, P. (1995). La generación del '80 en Mendoza (1880-1905). Mendoza: Ediunc.

Lomnitz, C. (2006). La idea de la muerte en México. México: FCE.

Mateu, A. M. (2004). Entre el orden y el progreso (1880-1920). En A. Roig, P. Lacoste y Satlari, M. C. (Comps.), Mendoza a través de su historia (pp. 245-280). Mendoza: Caviar Blue.

Mazzeo, C. (2006). El "Padre del Federalismo y Protector de los Pueblos Libres". José Gervasio Artigas y la creación del ideario nacional en Uruguay, 1856. En C. McEvoy (Ed.), Funerales Republicanos en América del Sur: Tradición, ritual y nación, 1832-1896 (pp. 101-123). Chile: Centro de Estudios Bicentenarios, UC. 
66 | Muerte y política: los funerales de Rufino Ortega...

McEvoy, C. (Ed.) (2006). Funerales Republicanos en América del Sur: Tradición, ritual y nación, 1832-1896. Chile: Centro de Estudios Bicentenarios, UC.

Nora, P. (2008). Les Lieux de mémoire. Montevideo: Trilce.

Olguín, D. (1965). Lencinas, el caudillo radical. Historia y mito. Mendoza: Vendimiador.

Oviedo, J. (2010). El periodismo de Mendoza. Buenos Aires: Academia Nacional de Periodismo.

Persello, V. (2010). Los gobiernos radicales: debate institucional y práctica política. En R. Falcón (Dir.), Democracia, conflicto social y renovación de ideas (1916-1930) (pp. 59-100). Buenos Aires: Editorial Sudamericana.

Persello, V. (2011). Los opositores radicales a Yrigoyen. PolHis, 7, 132-139.

Ponte, R. (1999). La Fragilidad de la Memoria. Mendoza: Ediciones Fundaciones CRYCIT.

Rader, O. (2006). Tumba y poder. El culto político a los muertos desde Alejandro Magno hasta Lenin. Madrid: Siruela.

Reyes, F. (2016). “Conmemorar la Revolución y sus mártires” sobre el lugar de un ritual político en la constitución de la identidad del radicalismo (1891-1897). Estudios Sociales, 50, 41-76.

Richard Jorba, R. y Bragoni, B. (1998). Empresarios-políticos y el control del Estado. Renovación en la élite y construcción de una economía regional en el marco nacional. Mendoza, Argentina. 1850-1890. Historia y grafía, 11, 13-38.

Richard Jorba, R. (2009). Empresarios ricos, trabajadores pobres. Vitivinicultura y desarrollo capitalista en Mendoza (1850-1918). Rosario: Prohistoria.

Richard Jorba, R. (2013). Somos el pueblo y la patria. El populismo lencinista en Mendoza frente al conflicto social y la prensa: discursos, representaciones y acciones, 19171919. Revista de Historia Americana y Argentina, 48, 11-54.

Rodríguez Jiménez, P. (2012). Cuerpos, honras fúnebres y corazones en la formación de la República colombiana. Anuario Colombiano de Historia Social y de la Cultura, 38, 155179.

Rodríguez, C. (1979). Lencinas y Cantoni. El populismo cuyano en tiempos de Yrigoyen. Buenos Aires: Editorial Belgrano.

Satlari, M. C. (2004). El Estado de bienestar (1918-1955). En A. Roig, P. Lacoste y M. C. Satlari (Comp.), Mendoza, a través de su historia (pp. 289-334). Mendoza: Caviar Blue.

Verdaguer, J. (1933). Historia Eclesiástica de Cuyo. Milano: Premiata Scuola Tipografica Salesiana.

Para citar este artículo:

Aguerregaray Castiglione, Rosana (2018). Muerte y política: los funerales de Rufino Ortega y José Néstor Lencinas (Mendoza, principios del siglo XX). Anuario de la Escuela de Historia Virtual, 13, 42-66. 